\title{
A REVIEW ON COMMERCIALIZATION OF SMALLHOLDER AGRICULTURAL PRODUCERS AND ITS IMPACTS ON HOUSEHOLD LIVELIHOODS. EVIDENCE FROM ETHIOPIA CONTEXT
}

\author{
Abdissa Abe Neme ${ }^{1 凶}$, Tesfaye Lemma Tefera ${ }^{2}$ \\ ${ }^{1}$ Madda Walabu University, Ethiopia \\ ${ }^{2}$ Haramaya University, Ethiopia
}

\begin{abstract}
In developing countries like Ethiopia, the agricultural sector commercialization is the primary objective for smallholder agricultural producers to eradicate food insecurity and depart from subsistence farming to profit maximization in a production system in which households produce market-oriented products based on consumer preferences. However, the participation of smallholder farmers in the agricultural sector commercialization remains low due to various factors. These include high population growth with limited landholding system (land tenure), lack of capital and access to credit (collateral), poorly linked market access, high transaction costs, poor infrastructure, and weak institutions causing transaction costs to rise and considerably alter production and market-participation decisions in the commercialization of smallholder farming. The current government introduced market-oriented policies aimed at poverty reduction to overcome all these constraints in the last five years.
\end{abstract}

Keywords: commercialization, agriculture, farmers, income, impacts

\section{INTRODUCTION}

In sub-Saharan African countries, agriculture is the source of economic growth, and well-developed poverty reduction strategies aim to strengthen market-led agricultural development to stimulate economic growth (Sheleme, 2019). These countries have abundant agricultural resources and diverse ecological zones. Their economies are dependent on agriculture to a large extent. Over $85 \%$ of their populations live in rural areas where crop production and animal husbandry are main livelihood activities. These sectors contribute about $35.8 \%$ of GDP and $70 \%$ of foreign exchange earnings. Agriculture also provides $72.7 \%$ of the population with paid employment opportunities (CIA, 2018; World Bank, 2015; NPC, 2016).

Like in other sub-Saharan African countries, in Ethiopia, the agricultural sector contributes about $44 \%$ of the gross domestic product (GDP), $80 \%$ of employment, and $90 \%$ of export earnings. However, smallholder farmers, who constitute the bulk of the rural poor, have not fully benefited from agriculture's multiple functions because they predominantly practice subsistence agriculture, which excludes them from the formal market system and the related income-mediated benefits (CSA, 2015).

According to the Ministry of Agriculture and Rural Development (MoARD, 2014), the government of Ethiopia has prioritized agricultural commercialization as a policy agenda included in the Poverty Reduction Strategy Paper (PRSP) since 2005. The objective is the departure of smallholder farmers from subsistence farming

\footnotetext{
$\bowtie$ Abdissa Abe Neme, Department of Rural Development and Agricultural Extension, Madda Walabu University, Bale Robe, 247, Ethiopia, e-mail: abe.kufa789@gmail.com
} 
to profit maximization and a production system in which households produce market-oriented products based on consumer preferences. In commercialization, smallholder farmers employ intensive agriculture to improve land use, labor, implements, and introduce improved inputs, including seeds, fertilizer, agrochemicals, and even mechanized farming system to increase crop and animal production to maximize the profit by increasing market share or sell rather than consume the products.

Agricultural commercialization also refers to the progressive shift from household production for own consumption to production for sale on the market. This shift means that production and input decisions are based on profit maximization, reinforcing vertical linkages (additional activities, including processing, packing, and milling to add value to the products rather than selling the products only) between input and output markets (Olwande et al., 2015). Processing in smallholder commercialization is part of an agricultural transformation process in which individual farms shift from a highly subsistence-oriented production to more specialized production targeting markets, both for input procurement and output supply (Asfaw, 2019; Abdu et al., 2016).

However, the participation of smallholder farmers in commercial farming remains low due to different factors. Examples of such factors include high population growth with limited landholding system (land tenure), lack of capital and access to credit (collateral), poorly linked market access, high transaction costs, poor infrastructure, and weak institutions causing transaction costs to rise, which considerably alter production and market-participation decisions in the commercialization of smallholder farming (Sheleme, 2019; Amsalu, 2014). In addition, several challenges hinder smallholder farmers from participating in agricultural commercialization rather than subsistence farming, including property rights, seed money for improved inputs, irrigation, extension system, rural infrastructure, storage, connection to markets, and the volatility of food prices often because of events beyond the control of developing countries (Adisu, 2018; Ahmed, 2017).

Moreover, the transformation of subsistence agricultural production into a commercially oriented system requires two essential dynamics to promote commercialization and encourage smallholder farmers to start market-oriented production. The first one concerns efficient market services for timely delivery of quality inputs to farmers at competitive prices. And the second one involves transparent output markets providing signals to farmers that help them make informed decisions on product type and quality standards and information on the best place and time to sell their outputs and markets to focus on (ATA, 2017; Asfaw, 2019).

Therefore, agriculture commercialization driven by small-scale and resource-poor farmers has the potential to increase household food security, reduce rural poverty, and contribute to agricultural development and economy-wide growth by encouraging the application of improved agricultural inputs and farming techniques, diversification of low-yielding subsistence crops, and specialization in more tradable crops. Commercialization can also increase farming incomes, enhance purchasing power, and reduce vulnerability among smallholders (Abdu et al., 2016). This paper aims to synthesize the agricultural commercialization of smallholder farmers toward improving rural livelihoods in Ethiopia.

\section{The rationale for promoting agricultural commercialization of smallholder producers}

Agricultural commercialization usually involves a long transformation process through three consecutive stages from subsistence to semi-commercial and then to fully commercialized agriculture (Moti et al., 2009). In the first stage, smallholder farmers produce more diverse crops with mainly subsistence production at farm level and intended for home consumption (75-100\%). Some of the yields can be taken to markets (0-25\%), leading to underdeveloped markets with high crop prices. Even if the market prices are high, smallholder production level declines due to different factors (Callier and Dercon, 2014; Dercon and Gollin, 2014).

In the second stage of agricultural commercialization, as a result of increased productivity due to diversification, smallholder farmers shift from the total (100\%) home consumption to some crops being taken to markets (25-75\%) because the opportunities come from the increasing demand for diversified and higher value crops. This, in turn, can improve the agricultural sector and the incomes of smallholder farmers who specialize in one or several products. At this stage, smallholder farmers tend to use inputs from the markets and increase market participation by selling the products. Financial-sector institutions such as banks start to support smallholder farmers during the typical season and risky situations (Pingali, 2019). 
Smallholder farmers produce more for commercial $(75-100 \%)$ than subsistence purposes in the final stage. The agricultural sector remains more diversified throughout agricultural transformation because farmers specialize in different products due to agronomic and climate factors. The household consumption pattern could also change from staple food to high-value crops like fruit, vegetables, fish, and livestock products substituted for starchy staples. With increasing commercialization, mechanical and chemical technologies will also replace human labor (source of knowledge but not energy) for more control-intensive operations such as weeding and harvesting, etc. (Pray and Nagarajan, 2014).

\section{The role of agricultural commercialization in households' food security}

Different studies indicate that commercialization plays a significant role in improving household food security, including livelihoods, rural smallholders' employment, income growth, food security, poverty alleviation, socio-economic development, and environmental sustainability (Jaleta et al., 2009). In a 2013 study, "The Role of Agricultural Commercialization for Smallholders Productivity and Food Security", Wondmagegn argued that commercialization directly affects household's income level, possibly leading to increase in food and non-food expenditure. However, household's food consumption expenditure can be analyzed by considering the effect of the price level as lower-income households may not enjoy an improvement in welfare if they face higher market prices. And households with higher income may have a better chance of enjoying commercialization, mainly in countries like Ethiopia, where a significant income share is spent on food.

The study by Samuel et al. (2016) on the commercialization of farming in Ethiopia reveals that the commercialization of smallholder farmers could improve households' welfare, promoting better living standards through consumption of high-value foods like vegetables, fruit, among others, purchasing high-quality equipment, better education for the children and overall improvement of quality standards. The study concludes that agricultural commercialization has a significant role in building households' welfare (Osmani et al., 2015).

Agricultural commercialization could also increase household consumption patterns in terms of numbers per-day and food security or nutritional contents, which ultimately depends on farm households' decision on allocating resources, including land, labor, time, and capital (Ogutu et al., 2017). For instance, land allocation for non-food cash crops may decrease household food supply unless the households have other off-farm income sources that could be used for food purchases (Benjamin et al., 2014; Shewaye, 2014).

According to Ahmed (2017), who studied agricultural production commercialization in Bangladesh, it plays a vital role in changing smallholder farmers' livelihood and improving their households. These welfare effects are represented by an increase in consumption of nongrain consumables (including sugar, coffee, salt, and cooking oil); kerosene consumption; and expenditure on shoes and clothes, education, healthcare, durable goods (bed, mattress, radio, TV, mobile etc.), housing (iron sheets, buildings etc.) and farm implements (ox plows and fertilizers, water pumps etc.) (Mudege et al., 2018).

\section{Determinants of smallholder agricultural commercialization in Ethiopia}

Numerous factors affect the commercialization of smallholder agriculture. These determinants are broadly categorized as external and internal factors. The external factors are beyond the smallholders' control. They include population growth and demographic change, technological change and introduction of new commodities, development of new infrastructure and market institutions, development of the non-farm sector and the broader economy, rising labor opportunity costs, macroeconomic, trade and, sectoral policies affecting prices and other driving forces (Asfaw, 2019; Abdu et al., 2016). On the other hand, internal determinants include factors such as smallholder resource endowments such as land and additional natural, labor, physical, and human capital (Moti et al., 2009; Mudege et al., 2018).

In addition, the development of market input and output, institution arrangement, including market regulations, production and market opportunities and constraints, property rights and land tenure, cultural and social factors affecting consumer preferences, agroclimatic conditions, and production and market-related risks constitute other external factors that could affect the commercialization process (Samuel et al., 2016). The degree of commercialization is influenced by a combination of demographic, social, economic, logistic, and climate change factors, indicating the need for a comprehensive approach to commercialization (Gutu, 2017; Ahmed, 2017). 
On the other hand, factors like smallholder resource endowments, including land and natural, labor, physical, and human capital, among others, are householdspecific and considered to be internal determinants. In general, significant determinants of smallholder farmers' commercialization are classified into eight categories. These include population growth and demographic change, technologies, institutions, risks (concerning not only production and prices but also access to inputs and markets and enforcing contracts), markets and their integration, transaction costs (buyers and sellers protect themselves against risks of a transaction failure by searching for and screening potential suppliers or buyers and their goods and services, then negotiating and contracting them, monitoring and enforcing their adherence to the contract), asset holdings of the households and policy aspects (Gutu, 2017; Moti et al., 2009; Samuel et al., 2016; Habtamu et al., 2014).

\section{Measurements of agricultural commercialization}

Agricultural commercialization tends to be measured when smallholder farmers produce a significant amount of cash commodities, allocating a proportion of their resources to marketable commodities and selling the expected amount of their agricultural outputs (Degye et al., 2012). Agricultural commercialization can also be measured in terms of market share, input and output usage, access to nutritional values, and smallholder livelihood improvement (Ele et al., 2013; Lipkova and Braga, 2016). However, the meaning of commercialization goes beyond merely supplying surplus products to markets. It also considers both the input and output production and the decision-making behavior of farm households in production and marketing simultaneously.

Therefore, various scholars (Degye et al., 2012) argued that commercialized farmers' production decisions are based on comparative advantages and market signals. In contrast, subsistence farmers' decisions are based on subsistence requirements, production feasibility, and selling only the surplus left after household consumption requirements are met. It concludes with the three indicators of agricultural commercialization at a household level: output and input commercialization, commercialization of rural economy, and the degree of household integration into the cash economy. The commercialization index is continuous and ranges between zero (0) and one (1).

$\begin{aligned} & \text { 1(a) Commerciali- } \\ & \begin{array}{l}\text { zation of agricul- } \\ \text { ture (output side) }\end{array}\end{aligned}=\frac{\begin{array}{c}\text { Value of agricultural sales } \\ \text { on markets }\end{array}}{\begin{array}{c}\text { Agricultural production } \\ \text { value }\end{array}}$

1(b) Commer-

cialization of agriculture

(intput side)

Value of inputs acquired from

$$
\begin{aligned}
& =\frac{\text { markets }}{\text { Agricultural production }} \\
& \text { value }
\end{aligned}
$$
(2) Commerciali- zation of rural economy

Value of goods and sevices acquired through market transactions Total income

Value of goods and sevi-

(3) Degree of integration into ces acquired through cash transactions cash economy

Source: Ogutu et al., 2017.

In addition to the above, agricultural commercialization can be measured in terms of the average income gained from sold crops by households to the gross value of the total crops produced by them, known as the household crop commercialization index (CCI). It is represented as follows (Amsalu, 2014)

$$
\text { CCI }(i)=\frac{\begin{array}{l}
\text { Gross value of crop sales } \\
(\text { hhi, year } j)
\end{array}}{\begin{array}{l}
\text { Gross value of total crop } \\
\text { production }(\text { hhi, year } j)
\end{array}} \times 100
$$

Source: adapted from WB, 2015.

According to this formula, the process of agricultural commercialization represents the continuum, ranging from $(C C I(i)=0)$ only subsistence to a completely commercialized production system $(C C I(i)=100)$

However, the calculation of commercialization has its limitations. The commercialization index calculation requires price data collected from different farmers who observed when farmers sold their commodity. Still, there are many missing values; some farmers produce commodities only for consumption, and some sales prices are endogenous, depending on quantities, types 
of market chosen for a transaction, and other factors (Ogutu et al., 2017).

The impact of agricultural commercialization on household income and poverty reduction Agricultural commercialization produces both positive and negative impacts on smallholder producers and intended and unintended results at household, societal and global levels (Zhou et al., 2013).

The research conducted by Moti et al. (2009) revealed that the impacts of commercialization could be categorized into first, second, and third-order. The first order includes mainly income and employment effects that are directly reflected in household welfare. The second-order effects include health and nutrition aspects usually contingent on the level of income attained through the existing level of commercialization. The third-order (traditionally known as higher-order) effects are the macro-economic and environmental effects beyond the household level. However, the impact of agricultural commercialization can be classified into two broad categories: positive and negative, which are detailed in the subsequent section.

\section{Positive effects}

At the household level, studies by IFPRI (International Food Policy Research Institution) in Africa credited agricultural commercialization with a positive impact on rural households by increasing their productivity, family employment, improving household income through market participation and work, upgrading consumption diversity, nutritional welfare, education, health, general welfare, and household living standards (von Braun and Kennedy, 1994). The same studies revealed that at the societal level, commercialization contributes to food security, poverty alleviation, rural and urban employment creation, improved livelihoods and social status, as well as economic growth by increasing investment and productivity. The World Bank (2015) further credited commercialization with creating rural markets for agro-inputs and rural supply bases for urban industries and consumers, increased economic investment in agriculture and other sectors through trade, and environmental sustainability of agricultural production. In Zimbabwe, Moyo (2010) observed increased productivity in food crops due to cotton commercialization as farmers increased use of high-productivity inputs purchased with cotton income. Similar effects on income and productivity were also observed in Malawi's tobacco production (Leavy and Poulton, 2007), Botswana's beef production (Samuel et al., 2016), and Zambia's maize production (von Braun and Kennedy, 1994). Most of the positive results are income-mediated as increased household income is used to finance household welfare and investment in society and other enterprises. Above all, results confirm that commercialization has a positive role in livelihood improvement, rural development, and poverty reduction.

\section{Negative impacts}

Mixed results reported in studies have caused some questions to be raised regarding the nutritional, welfare, and environmental sustainability role of commercialization (Gebreselassie and Sharp, 2007). According to von Braun and Kennedy (1994) and Asfaw et al. (2019), commercialization is criticized for failing to improve household nutrition and livelihoods of the poorest, replacing subsistence risk with more complex market risk, failing to guarantee household food security, and opposing food self-sufficiency objectives. It is criticized for widening regional income inequalities, land degradation through chemicals, and being an expensive and risky undertaking, especially for the poorest (Pingali, 2007). However, Lerman (2004) argued that these claims are not satisfactorily substantiated as some criticism leveled against commercialization result from the failure on the part of policies, strategies, institutions, attitudes, and distribution of benefits and costs within households and communities. Although some negative results are reported, the positives outweigh the criticism and underscore the need for commercialization. However, more empirical research is needed on its effects to find conclusive results.

\section{CONCLUSION AND POLICY IMPLICATIONS (RECOMMENDATIONS)}

Ethiopia is one of the sub-Saharan African countries whose agriculture shows a highly liberalized economy and a strong emphasis on poverty reduction policies aimed at strengthing market-led strategies for agricultural development and economic growth. The abundance of resource allocation and diverse ecological zones favors the agriculture sector as an attractive and dominant sector. Although agriculture contributes around $44 \%$ of the country's GDP, smallholder farmers, especially the rural 
poor, have not fully benefited from the sector because they predominantly practice subsistence agriculture, which prevents them from participating in the formal market system and enjoying income-mediated benefits.

The current government has been emphasizing the role of this sector by prioritizing farming commercialization in its agenda since 2005 . A poverty reduction strategy was prepared to help smallholder farmers switch from subsistence farming to profit maximization by encouraging them to produce market-oriented production based on customer preferences. This may be achieved through intensive agriculture and modern agricultural inputs.

However, several challenges limit agricultural commercialization effectiveness due to various factors. Some of them include high population growth with limited landholding system (land tenure), lack of capital and access to credit (collateral), poorly linked market access, high transaction costs, poor infrastructure, and weak institutions causing transaction costs to rise and considerably alter production and market-participation decisions in the commercialization of smallholder farming.

In conclusion, in the transformation of agriculture from subsistence to market-oriented, two essential dynamics need to be addressed to promote commercialization and encourage smallholders to switch to market-oriented agricultural production. Firstly, efficient market services for the timely delivery of quality inputs to farmers at fair prices are needed. And secondly, transparent output markets are required to help smallholder farmers make informed decisions on product type and quality standards and provide information on the best place and time to sell their outputs at low transaction costs. Additionally, smallholder farmers need to be encouraged to employ highly advanced agricultural innovations to increase output production.

\section{REFERENCE}

Abera, S. (2014). Determinants of Haricot bean Commercialization: The Case of East Badawacho District, South Nations Nationalities and Peoples Regional State, Ethiopia. An MSc Thesis Presented to the Haramaya University, Haramaya, Ethiopia.

Abu, B.M., Bonsu, Y.O.A., Seini, W. (2014). Market participation of smallholder maize farmers in the Upper West Region of Ghana. Afr. J. Agric. Res., 9(31), 2427-2435.
Ahmed, T. (2017). Impacts Of Agricultural Commercialization On Smallholder Farmers In South-Western Region Of Bangladesh. Int. J. Econ. Comm. Res., 7(2), 33-40.

ATA (Agricultural Transformation Agency). (2017). Market service, the Agricultural Transformation Agency Ethiopia sustained development to end poverty. Addis Ababa.

Bezabih, A. (2018). Malt barley commercialization through contract farming scheme: A systematic review of experiences and prospects in Ethiopia. Afr. J. Argic. Res., 13(53), 2957-2971.

Boka, G.T. (2017). Climate change challenges, smallholder commercialization and progress out poverty in Ethiopia. Working paper series No 253.

CIA (Central Intelligence Agency). (2018). World fact book. Ethiopian economy Profile.

CSA (Central Statistical Agency). (2015). The federal democratic republic of Ethiopia central statistical agency key finding agricultural sample survey.

Dercon, S., Gollin, D. (2014). Agriculture in African development: theories and strategies. Ann. Rev. Res. Econ., 6, 471-492.

Ele, I.E. (2013). Assessing the Extent of Commercialization of Smallholding Farming Households in Cross River State, Nigeria. IOSR J. Agric. Vet. Sci., 4(2), 49-55. Retrieved from: https://www.researchgate.net/publication/271255754_Assessing_the_Extent_of_Commercialization_of_Smallholding_Farming_Households_in_ Cross_River_State_Nigeria

Gebreselassie, S., Sharp, K. (2007). Commercialization of Smallholder Agriculture in Selected Tef-Growing Areas of Ethiopia. Ethiop. J. Econ., 16(1), 57-88.

Goshu, D., Kassa, B., Ketema, M. (2012). Measuring smallholder Commercialization Decisions and Interactions in Ethiopia. J. Econ. Sust. Dev., 3(13), 150-160.

Jaleta, M., Gebremedhin, B., Hoekstra, D. (2009). Smallholder commercialization: processes, determinants and impacts. ILRI Discussion Paper 18. Nairobi, Kenya.

Jebesa, S.R. (2019). Determinants of smallholder farmers market participation and outlet choice decision of agricultural output in Ethiopia: A review. Am. J. Agric. Forest., 7(4), 139-145.

Leavy, J., Poulton, C. (2007). Commercialization in agriculture. A work shop paper future agriculture, schools oriented an African studies. University of London, London.

Lerman, Z. (2004). Policies and institution for commercialization in subsistence farming in transistion countries. J. Asian Econ., 15(3), 461-479.

Lipkova, L., Denys, B. (2016). Measuring commercialization success of innovations in the EU. Bratislava, Slovak Republic. 
Mitiku, A. (2014). Impact of smallholder farmers agriculture commercialization on rural household s poverty. Int. J. Appl. Econ. Fin., 8(2), 51-61.

MoARD (Ministry of Agriculture and Rural Development) (2014). Food Security Program 2010-2014. Ministry of Agriculture and Rural Development. Addis Ababa, Ethiopia.

Mohammed, A., Baze, M., Ahmed, M. (2016). Smallholder commercialization and commercial farming in coffeespice based farming system of south west Ethiopia. Int. J. Res. Stud. Agric. Sci. (IJRSAS), 2(5), 13-26.

Moyo, T. (2010). Determinants of Participation of Smallholder Farmers in the Marketing of Small Grains in the Limpopo River Basin of Zimbabwe, Unpublished MSc. Thesis.

Mudege, N.N., Kebaara, K., Mukewa, E. (2018). Effects of commercialization of sweetpotato on gender relations and wellbeing among smallholder farmers V-89 November 2018, Nairobi.

NPC (National Plan Commission). (2016). Growth and Transformation Plan II (GTP II), National Plan Commission (vol. I). Main text Addis Ababa. 14

Ogutu, S.O., Godecke, T., Qaim, M. (2017). Agricultural commercialization and nutrition in small farmhouseholds. Global food discussion paper 97. University of Gettingen.

Olwande, J., Smale, M., Mathenge, M.K., Place, F., Mithöfer, D. (2015). Agri. marketing by smallholders in Kenya: A comparison of maize, kale and dairy. Food Polic., 52, $22-32$.

Osmani, M.A.G., Khairul, I., Bikash, C.G., Hossain, M.E. (2015). Commercialization of smallholder farmers and its welfare outcomes. Evidence from Durgapur Upazila of Rajshahi District, Bangladesh. J. World Econ. Res., 3(6), $119-126$.

Pingali, P. (2007). Agricultural growth and economic development. Agric. Econ., 37(3), 1-12.

Pray, C.E., Nagarajan, L. (2014). The transformation of the Indian agricultural input industry: Has it increased agricultural R\&D? Agric. Econ., 45(S1), 145-156.

Senbeta, A.N. (2019). Determinants and Impacts of Smallholder Agricultural Commercialization in Ethiopia. Review paper. Int. J. Agric. Agribus., 1(1), 124-132.

Tirkaso, W.T. (2013). The role of agricultural commercialization for smallholders productivity and food security an empirical study in rural Ethiopia. Master thesis. Uppsala 2013.

Von Braun, J. (1994). Production, employment and income effects of commercialization of agriculture. In: J. von Braun, E.T. Kennedy (Eds.), Agricultural commercialization, economic development, and nutrition (chap. 3, pp. 37-64). Baltimore, MD, Johns Hopkins University Press.

World Bank (2015). 4th Ethiopia economic update: Overcoming constraints in the manufacturing sector World Bank report. Addis Ababa, Ethiopia.

Yesigat, H.A., Sauer, J., Abate-Kassa, G. (2015). On smallholder farmers' exposure to risk and adaptation mechanisms: panel data evidence from Ethiopia. Conference: 89th Annual Conference, April 13-15. Warwick University, Coventry, UK. 
